\title{
Digital technologies and improvement of training of the mobilization reserve and military-patriotic education at military departments of civil universities
}

\author{
Zufar Burnayev ${ }^{1}$, Aydin Ryskulbekov ${ }^{2}$ \\ ${ }^{1}$ National University of Defense of the First President of the Republic of Kazakhstan - Elbasy, Nur-Sultan, \\ Kazakhstan, burnayev.zufar@inbox.ru \\ ${ }^{2}$ National University of Defense of the First President of the Republic of Kazakhstan - Elbasy, Nur-Sultan, \\ Kazakhstan, ryskulbekov.aidyn @bk.ru
}

\begin{abstract}
In modern conditions, at the stage of professionalization of the armed Forces of the Republic of Kazakhstan, it is necessary to re-focus on their own forces, concentrate intellectual and technical, engineering potential for the further development of the national system of military education and military science. Digital development, new computer technologies, mechanical engineering with the help of the latest computer technologies can improve the development of scientists in the field of defense industry.
\end{abstract}

Key words : engineering, technology, training, mechanics, digital technologies

\section{INTRODUCTION}

In modern conditions, at the stage of professionalization of the Armed Forces of the Republic of Kazakhstan, it is necessary to re-focus on their own forces, to concentrate intellectual and financial potential for the further development of the national system of military education and military science.

Elbasy in the program "Looking to the future: modernization of public consciousness", notes: education is the most fundamental factor of success in the future. In the system of priorities for young people, education should be the first number." This requirement contributes to the improvement of the system of military education of the armed forces and implementation of policies of the First President of the Republic of Kazakhstan N. And.Nazarbayev in the Strategy "Kazakhstan-2050 New political course of the established state".

According to the Military doctrine of the Republic of Kazakhstan dated September 29, 2017, further improvement of the system of training the mobilization reserve in the military departments of higher educational institutions of the
Republic of Kazakhstan will be implemented in the following areas:

- bringing the system of training military specialists in line with the needs of the Armed forces, other troops and military formations;

- introduction and development of demanded specialties for the military organization of the state;

- optimization of the composition and structure of military departments at higher educational institutions, eliminating duplication of training of specialists in them.

The need to develop ways to improve the training of officers and sergeants of the reserve of the Armed Forces of the Republic of Kazakhstan lies in the fact that it lays the Foundation for deep systemic changes in order to prepare the mobilization reserve of the Republic of Kazakhstan and recruit the Armed Forces, other troops and military formations of the Republic of Kazakhstan in peacetime.

Based on the analysis of foreign experience and the current state of the system of training the mobilization reserve in higher educational institutions of Kazakhstan, the article defines the main directions of development of military departments at higher educational institutions of the Republic of Kazakhstan-centers of military and Patriotic education of youth, as well as offers ways and specific mechanisms for development.

2. ANALYSIS OF FOREIGN EXPERIENCE (RUSSIAN FEDERATION, REPUBLIC OF BELARUS, UNITED STATES OF AMERICA, GREAT BRITAIN, FRANCE)

The need for advanced training of mobilization reserves, including reserve officers and sergeants, remains in our time. This is confirmed by the experience of wars and local conflicts of our time. In the leading countries of the world, the system of military training in higher educational institutions plays a major role in the training and accumulation of military-trained reserves.

Currently, in some military districts of the Armed Forces of the Russian Federation, the number of officers called up for military service from the reserve is $20 \%$ of the total number of 
all district officers, and their share in primary positions reaches $50 \%$. On the basis of the military departments of civil universities in the Russian Federation (RF), 33 military training centers for cadre and reserve officers in humanitarian, engineering and technical profiles were initially created.

Students who have signed a training contract, on the day after graduation, sign a contract for a period of 3 years or 5 years, and begin military service with the rank of Lieutenant. 1,500 hours of training time, including training fees (internships), are allocated for the military training of cadre officers who are trained in the programs of military training centers.

The reserve officer training program provides 450 hours of classroom instruction and 144 hours of training time at training camps. Students study academic disciplines based on the knowledge they receive during the development of special disciplines in the main educational program of the University. A student at a military training center is paid a monthly additional scholarship, as well as a one-time payment for the purchase of a special form of clothing in accordance with the procedure and amounts established by the Government of the Russian Federation.

Main tasks of the military training center:

1) implementation of the program of military training of citizens;

2) participation in educational work among citizens and work on military-professional orientation of young people.

Currently, there are 93 military training centers in the Russian Federation, where the training of career officers is 10,500 people, reserve officers-34,200 people, sergeants and reserve soldiers $-16,500$ people.

Republic of Belarus. Higher military-special education is done for the 5-year program of study first degree at the Military Academy of the Republic of Belarus, and in certain specialties - military departments of universities, in Ináhigher other States. Military personnel who have received higher military special education are awarded the military rank of Lieutenant. They are sent for further service in the army. Gifted graduates of academic groups who have shown an aptitude for research, if there is a request from their scientific supervisors, are sent for further training at the second stage in the master's and associate's programs.

Military training at the military faculties of 7 higher education institutions of the Republic of Belarus (RB) is carried out according to the training programs for officers of the tactical level (personnel) in more than 20 specialties.

The main tasks of the faculties include:

- preparation of students in programs of training of career officers;

- training of University students in reserve officer training programs;

- training of University students in Junior commander training programs;

- retraining and advanced training of specialists for the Armed Forces and military formations.

Persons who have entered the faculty acquire the status of military personnel from the date of signing the order by the
Deputy Minister of defense for personnel on their enrollment in the military faculty.

After the first year of training, cadets are individually awarded a contract for their military service for the period of study at the faculty and for military service as officers under contracts for 15 years in the armed forces of the Republic of Belarus. Cadets who do not sign such a contract are subject to expulsion from the faculty.

In the United States, the system of military training in higher education institutions is conducted in more than 600 civilian universities (almost 20\% of all functioning universities in the country) and is the most important source of recruitment of the US armed forces on a fully professional basis.

In the total number of officers in the US armed forces, graduates of military training courses at universities make up about $70 \%$. Every year, on average, about $50 \%$ of graduates of military training courses enter the regular formations (about 4,000 officers per year only for the Land forces). The us Department of defense is interested in using the possibility of civilian universities to equip the Armed Forces with specialists of a narrow profile: doctors, physicists, chemists, engineers, as well as trained specialists for the structure of military intelligence.

Non-military training of officers in the course is carried out in two different programs: cadre and reserve officers. Cadre officers are contracted to serve in the US armed forces for a period of at least 4 years. Reserve officers are required to serve in regular or reserve formations for 8 years. All of them are considered cadets and are on state support.

The command of non-military training of officers of the US armed forces is constantly increasing attention to improving the quality of training of graduates of the non-military training system. For this purpose, the most intensive and practically directed programs of military training of students are developed. Each program is based on such priorities as instilling leadership skills and practical work, field (sea, air) training - the basis of combat training. In addition, much attention is paid to the theoretical and practical training of specialists in complex military-technical military accounting specialties.

Great Britain. According to the British Ministry of defence, through the system of non-preparation (SVP) is completed approximately one third of the officers of the armed forces, as well as two-fifths of Junior officers or non-commissioned officers, and experts (using "Junior" non-preparation at secondary and secondary special educational institutions). In total, about 150,000 students and students study in the non-military training system every year.

Non-military training courses are available in almost all British universities and some Polytechnic institutes and colleges. In total, there are 740 specialized secondary and 350 higher education institutions in the UK, including 47 universities (46 full-time and Open universities), 30 so-called polytechnics and other universities.

Each branch of the armed forces has a separate headquarters for non-military training of command personnel, which is 
located at the basic school of this type. SVP headquarters manage subordinate courses (divisions) and military departments ("military departments") of civil educational institutions in the specialties of the corresponding type of the armed forces. Coordinates the activities of all three services headquarters at the military school Sandhurst. The latter is accountable to higher command authorities - the bodies of the Central apparatus of the Ministry of defense of the United Kingdom, which include representatives of the service of non-military training and training of reserve formations.

The term of study is usually (on average) 3 years, which corresponds to the period of study at the University. During each semester, classes are held 1-2 times a week for 2-4 hours (on the basis of the University), as well as during two-day weekend training sessions held 1-2 times a month on the basis of the University or a neighboring part. The school year ends with a two-week camp camp held during the summer holidays. Immediately before passing the military training exam, short-term training fees are provided for preparing for the exam.

France. Currently, more than 50 civilian training institutions are used in France to train officers. In addition to higher education institutions, the SVP traditionally includes secondary specialized educational institutions, which, in particular, include civil lyceums in Paris, Nancy and Toulon. According to official French military sources, in recent years there has been a clear trend of increasing the number of officers entering the service after graduating from civil universities, in relation to officers who graduate from military schools. Reserve officers make up approximately $30 \%$ of the total army officer corps, including regular and reserve formations. Of them (that is, from almost $1 / 3$ of the officers), about $50 \%$ of reserve officers are graduates of universities in technical specialties, and the other $50 \%$ are graduates of law and Economics departments of institutes, as well as trade and management schools.

Traditionally, military training of students in the medical service profiles is carried out. In 1986, a mandatory training course in military medical specialties was introduced, which is held at the training center for reserve officers of the medical service (Liburn). Military medical training involves graduates of medical institutions who have successfully passed the University training program. Moreover, graduates of medical schools are called to training camps for training in the reserve officers ' program without fail (as cadets).

As you can see, in France, considerable attention is paid to the promotion of military training of students and students, the development of the structure and functions of the SVP as one of the main sources of recruitment of reserve officers and career officers. In particular, through the "Junior stage" of the SVP, that is, in lyceums, potential candidates for both reserve officers and career officers are prepared.

In General, the analysis of the organization and content of military training programs in various educational institutions in France shows that in this case there is already an established and quite extensive system, the functions of which are gradually expanding in connection with the transition to professional principles of recruitment of the armed forces. Thus, the study of the experience of organizing the training of reserve officers in foreign civil universities has shown the following.

Non-military training in civilian educational institutions has been developed in all leading foreign countries. SVP, in aggregate, are characterized by such qualitative parameters as:

- professionalism (both in relation to the contractual basis of military service, and in the sense of highly effective General training of graduates);

- comprehensive material and logistical support that encourages the organization and implementation of military training;

- rationality, universality and complexity of the structure (including all organizational components);

- the scale and degree of coverage of educational structures and contingents of students (in relation to all levels of education and in quantitative terms);

- long-term, on a historical scale, experience of using civilian educational institutions for the construction of the armed forces.

Analysis of the current situation in the Republic of Kazakhstan. Military training of citizens at the military departments of higher education institutions of the Republic of Kazakhstan for the training of reserve officers is organized and carried out in order to prepare the mobilization reserve of the Republic of Kazakhstan for military accounting specialties on the basis of higher professional education. Also, graduates of military departments are an additional source of recruitment for primary officer positions in the Armed Forces of the Republic of Kazakhstan.

The military Department is a structural division of the University.

There are a total of 34 military departments at universities in the Republic (figure 1 - as of 2018), including:

- in the Northern region-10 departments (Eurasian national University, Kazakh agrotechnical University, Kazakh humanitarian law University, JSC "Astana Medical University", JSC Financial Academy, Karaganda state technical University, Kokshetau University, North Kazakhstan state University, Kostanay state University); - in South region - 15 departments (Kazakh national University, Kazakh national research technical University, Kazakh national agrarian University, Kazakh national pedagogical University, JSC "Narkhoz", Kazakh University of international relations and world languages, Kazakh national medical University, Academy of civil aviation, international University of information technology, South Kazakhstan pedagogical state University, South Kazakhstan state University, South Kazakhstan medical Academy, Taraz state University, Kyzylorda state University, Zhetysu state University);

- in the Eastern region-4 departments (East Kazakhstan state technical University, State medical University, Kazakh 
Humanities and law innovation University, Pavlodar state University);

- in the Western region-4 departments (West Kazakhstan agricultural and technical University, West Kazakhstan state medical University, Caspian state University of technology and engineering, Atyrau state University).

Analysis of the activities of military departments, training of reserve officers showed that most departments successfully cope with their tasks. The growth of their popularity is evidenced by the fact that in recent years the number of students who want to study is many times higher than the established recruitment standards for military accounting specialties.

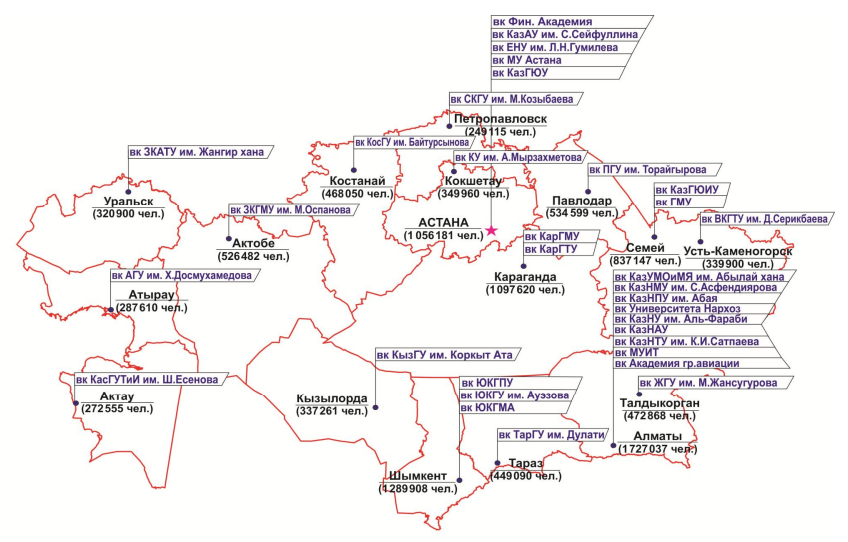

Figure 1: Deployment of military departments at civil universities of the Republic of Kazakhstan

* Note: The number of inhabitants is indicated under the city name.

Civilian universities are interested in having military departments, as this increases the prestige of the University, improves its funding, and allows for better selection of applicants. This is evidenced by a more than twofold increase in the number of military departments during the years of independence of Kazakhstan (from 14 - in 1990, 22-in 2000, 25 - in 2012, 29 - in 2018 and up to 34 - in 2019).

In 2019, the analysis of military accounting specialties in which military training of students was conducted at military departments showed that training in 30 of them is duplicated by several departments. This situation did not meet the current needs of completing the armed forces of the Republic of Kazakhstan and preparing the mobilization reserve. In this regard, the VUS was optimized, after which adjustments were made to reduce or exclude recruitment to the VUS, for which there is an oversupply of specialists with a corresponding increase in recruitment to new demanded VUS (territorial defense, ACS, IT-areas, cyber and information security, etc.). Thus, as a result, the number of specialties in the military departments of 70 specialties was 43 , for which since 2018 a set of students was made, which amounted to 5500 of them, 3700 on a grant and 1800 on a paid basis. According to the data DOMRAS of the General staff of armed forces of Kazakhstan in February of this year, according to the annual needs amount of training the mobilization reserve in the military departments, was made up of students in the military departments in 2019 , which amounted to 3700 just for the free training.

In this regard, it should be noted that changes in military accounting specialties for training students according to the recruitment plan, make serious problems for the preparation of appropriate educational material, educational and special literature, the availability and training of teaching staff due to the limited time for its preparation, approval and approval. Military training of students is organized and carried out by the method of "military day". Training at the military Department includes 2 years of training: 1 year-180 hours (2 semesters of 90 hours); 2 year - 180 hours ( 2 semesters of 90 hours). Training ends with a training camp (professional practice for girls), for students. The training camp is held in two stages: the first stage -90 academic hours on the basis of the military Department; the second stage-138 academic hours using the training material base of military units, military educational institutions according to the schedule approved by the Ministry of defense of the Republic of Kazakhstan.

Financing of military training of students on the program of reserve officers under the MES of RK, Ministry of health, Ministry of investments and development of Kazakhstan (military Department at the Academy of civil aviation), the Ministry of Finance (military Department at the Financial Academy).

The main ways to improve the system of training reserve officers and sergeants in higher educational institutions.

The study of foreign experience and the current state of the system of training the mobilization reserve in higher educational institutions of Kazakhstan allowed to determine the prospects for development and develop ways to improve it. First. It is necessary to introduce, in the first semester of training, the discipline "Military-Patriotic training" with a volume of 1 credit (30 hours). This discipline is taught to all 1 st year students of the University. In the future, when recruiting for the military Department, take into account, among other criteria, the results of training in this discipline. Military departments in the vast majority of universities are the main tool for conducting various organizational and mass events, centers of military professional orientation of students and military-Patriotic education. Carrying out the discipline "Military-Patriotic training" with all the trained contingent will strengthen the work in this direction.

Second. It is proposed to create a working group, whose work should be organized and carried out in three directions.

The first direction is engaged in making proposals for amendments to the legislation regarding the training of reserve sergeants (preparation and approval of all legal acts, including the development and implementation of the Order of the Minister of defense "on approval of the rules of military training for reserve officers (sergeants)").

The second direction is engaged in making proposals to amend the legislation in terms of renaming military departments to the faculties of military Affairs and Patriotic 
education (preparation and approval of all legal acts, including the draft Resolution of the Government of the Republic of Kazakhstan on the creation of faculties of military Affairs and Patriotic education on the basis of military departments at higher educational institutions of the Republic of Kazakhstan. In which to distribute the powers between the Ministry of defense of the Republic of Kazakhstan, the Ministry of education and science, Ministries and departments that are responsible for universities and rectors of universities on the management of the faculty and their comprehensive support).

The third direction is developing "Standards for providing training for reserve officers (sergeants)" taking into account the economic component.

The most important problem in the organization of training of reserve military personnel in civilian universities is the material and technical and methodological support of the educational process with students. The material and technical base of the majority of military departments does not meet modern requirements, a large number of assets listed for military departments are worn out and require replenishment, and insufficient funds are allocated for the purchase of simulators. It needs to be provided with samples and models of military equipment and weapons, taking into account the planned modernization and technical equipment of the Armed Forces in the near future. We need visual training posters, diagrams of new models of weapons and military equipment that are being received or will be received by the troops, taking into account the nomenclature of military accounting specialties for training reserve officers and sergeants.

A problematic issue in the process of training students in the military departments of higher education institutions of the Republic remains the lack of approved "Standards for the training of reserve officers (sergeants)". As a result, problems arise when staffing the educational and material base. The lack of these standards does not allow you to check the compliance of the educational material base, which undoubtedly affects the quality of training.

The third. We consider it expedient to switch to a two-level system of training of the mobilization reserve and introduce parallel training of Junior commanders (reserve sergeants) in civilian universities (with the training of reserve officers) with a period of one year and at the end of the 2 nd course of training training fees (using the material and technical base of the military unit, which is assigned to the military Department), lasting 30 hours (figure 2).

At the moment, only reserve officers are being trained in the country. The training of sergeants of the reserve as a mobilization reserve is not carried out. It became necessary to prepare them.

For training in the reserve officer training program, students are attracted who are ranked from the first number to the number corresponding to the number of allocated places according to the recruitment Plan for the reserve officer training program. For training under the reserve sergeants training program, students who are ranked from the first number to the number corresponding to the number of allocated places according to the recruitment Plan for the reserve sergeants training program are attracted.

Based on the results of competitive selection, the selection Committee makes 2 ratings (for officers and sergeants) in descending order of points.

Students who take the next place in the ranking in the number determined by the recruitment Plan for the reserve officer training program, and who have expressed a desire to undergo training under the reserve Sergeant training program (including on a paid basis) are attracted for training under the reserve Sergeant training program, but only if there are available places.
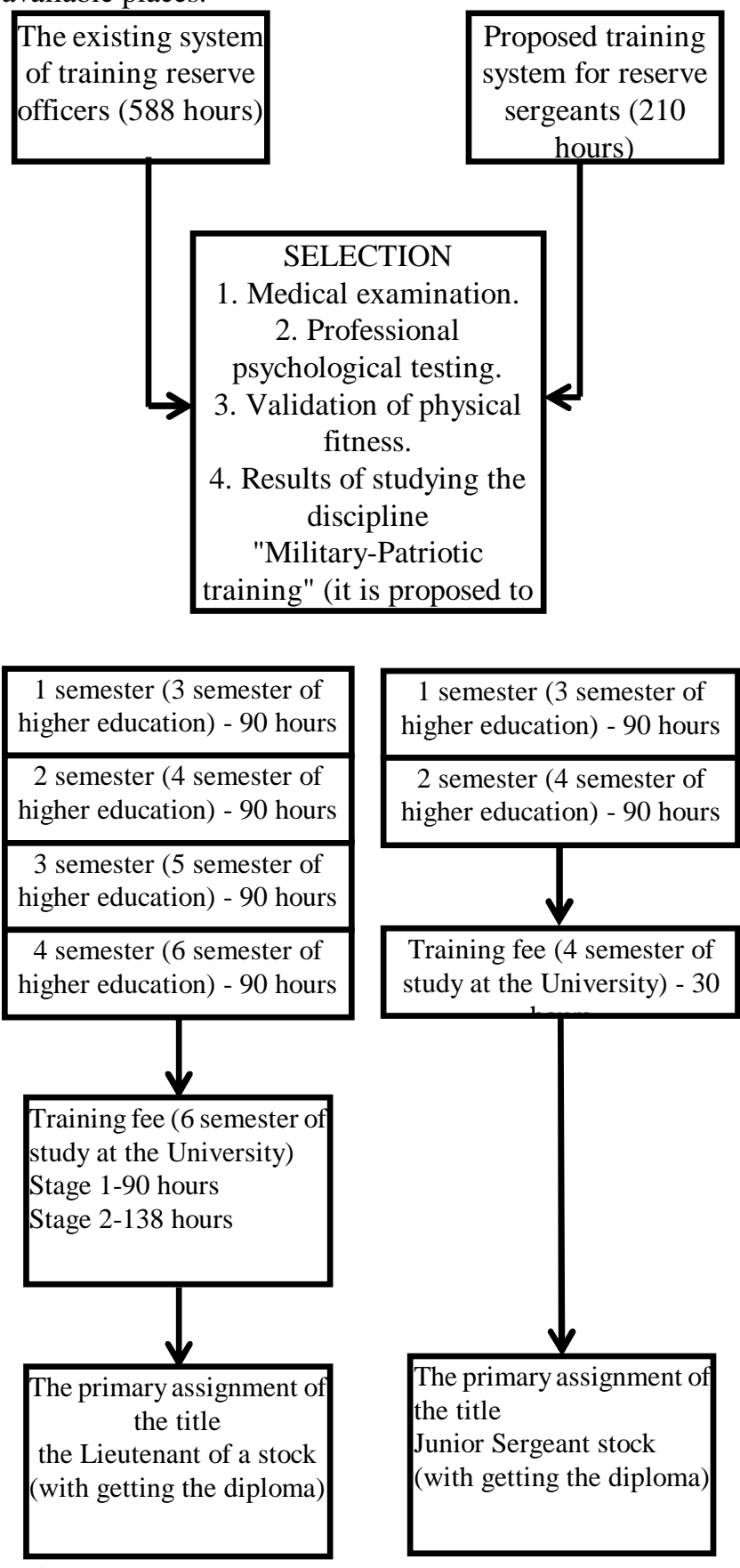

Figure 2: Proposed algorithm for training reserve officers and sergeants 
Fourth. In connection with the planned increase in the academic load and in order to increase the prestige of military departments, it is proposed to rename them the faculties of military Affairs and Patriotic education, consisting of: management; Department of reserve officers training and advanced training; Department of General military disciplines and training of reserve sergeants; military Patriotic club (figure 3).

As you know, the faculty is the main educational, scientific and administrative structural division of the University, which provides training in one or more related specialties, as well as management of research activities of departments and laboratories related to the specialties of the faculty. Thus, the main tasks of the faculty of military Affairs and Patriotic education will be:

1) training of reserve officers from among University students in the required specialties for the Armed Forces and other military formations;

2) training of reserve sergeants from among the University students in Junior military specialist training programs;

3) conducting scientific research;

4) education of patriotism, a high sense of responsibility for the performance of official duty for all students, under the bachelor's program, the staff of the University;

5 ) organization and conduct of advanced training courses.

The volume of military training will increase and there will be no threat for teachers to lose their jobs. Moreover, faculty teachers will be able to work at $1.25,1.5$ or 2 rates - which is practiced in universities in Kazakhstan.

The research work of the faculty's teaching staff will consist in the preparation and replication of educational (teaching and methodological) manuals, the preparation and publication of scientific articles and reports, obtaining patents and copyright certificates.

In the Order of the Minister of defense of the Republic of Kazakhstan dated July 24, 2017 No. 375, article 54 States "on the basis of the military Department, a military-Patriotic club is created", but in most departments, work in this direction is carried out at a low level. The inclusion of the military-Patriotic club in the organizational and staff structure of the faculty of military Affairs and Patriotic education will solve this issue.

The organization and conduct of advanced training courses with teachers-organizers of NVP secondary schools and colleges of the city will allow you to transfer the best practices of military training, to form the ideology and Kazakhstan's patriotism at the level of pre-University training.

Unified qualification requirements for the teaching staff. When developing uniform qualification requirements for the positions of the teaching staff of the faculty of military Affairs and Patriotic education, take into account the requirements of seniority, and only accept officers dismissed from the ranks of the armed forces of the Republic of Kazakhstan in the reserve (retired).

Head of the faculty (Dean). Qualification requirements: higher military education (military Academy, military University), military rank not lower than Colonel of the reserve (retired), experience in officer positions for at least 20 years.

Deputy head of the faculty for academic and scientific work. Qualification requirements: higher postgraduate education (military Academy, military University, master's degree), military rank not lower than Colonel of the reserve (retired), experience of scientific and pedagogical work or experience in officer positions for at least 20 years.

Head of department. Qualification requirements: higher military education (military Academy, military University), military rank not lower than Colonel of the reserve (retired), experience of scientific and pedagogical work or experience in officer positions for at least 20 years.

Deputy head of the Department. Qualification requirements: higher postgraduate education (military Academy, military University, master's degree), military rank not lower than Lieutenant Colonel of the reserve (retired), experience of scientific and pedagogical work or experience in officer positions for at least 20 years.

Professor. Qualification requirements: higher postgraduate education (military Academy, military University, master's degree), academic degree and academic rank, military rank not lower than Colonel of the reserve (retired), experience of scientific and pedagogical work or service experience in officer positions for at least 15 years.

Docent. Qualification requirements: higher postgraduate education (military Academy, military University, master's degree), academic degree and / or academic rank, military rank not lower than Lieutenant Colonel of the reserve (retired), experience of scientific and pedagogical work or experience in officer positions for at least 15 years.

Senior lecturer. Qualification requirements: higher postgraduate education (military Academy, military University, master's degree), military rank not lower than Lieutenant Colonel of the reserve (retired), experience of scientific and pedagogical work or experience in officer positions for at least 15 years.

Teacher. Qualification requirements: higher postgraduate education (military Academy, military University, master's degree), military rank not lower than reserve major (retired), experience in scientific and pedagogical work or experience in officer positions for at least 10 years.

The proposed implementation sequence. In order to improve the organization of training of reserve officers and sergeants in military departments at civil universities the following stages of implementation are proposed:

1) military departments remain at universities;

2) refrain from opening military departments at universities, as 34 departments, close in full the mobilization need for training reserve officers;

3) introduce, in the first semester of training, the discipline "Military-Patriotic training" with a volume of 1 credit (30 hours). This discipline is taught to all students of the 1st year of a civil University. In the future, when recruiting for the military Department, take into account, among other criteria, the results of training in this discipline; 
4) create a working group to prepare and approve all legal acts on the training of reserve officers and sergeants at the University and on the renaming of military departments to the faculties of military Affairs and Patriotic education;

5) the working group should also develop and approve "Standards for the provision of training for reserve officers (sergeants) »;

6) switch to a two-level system of training of the mobilization reserve and introduce in civilian universities that carry out military training of the mobilization reserve parallel (with the training of reserve officers) training of Junior commanders (reserve sergeants) with a one-year training period and 30-hour training fees;

7) rename the military departments in the faculties of military Affairs and Patriotic education, consisting of: management; Department of training of reserve officers and advanced training; Department of General military disciplines and training of reserve sergeants; military-Patriotic club;

8) annually conduct advanced training courses with teachers-organizers of NVP secondary schools and colleges of the city on the basis of the faculties of military Affairs and Patriotic education of the University;

9) from 2022, only reserve officers with academic degrees and titles should be appointed to civilian positions as Professor and associate Professor;

10) officers seconded by the Ministry of defense should be paid all the necessary additional payments until 2023, except for the official salary (salary for military rank, additional payment for class qualifications, child birth allowance, marriage registration allowance, compensation for housing sublease, etc.), however, the next military ranks should not be assigned to seconded officers working at military faculties;

11) in 2024, recall all seconded officers from the faculties, appointing reserve officers to civilian positions (retired).

Conclusion. The organization of training of reserve command personnel in civilian universities for the Armed Forces of other troops, military formations and bodies, ensuring the effectiveness of military training of students require significant efforts on the part of state authorities and military administration, University management, management and teaching staff of military departments. From planning and dedication of this work, from its financial and economic support, timely solutions to challenges depends largely on quality and quantity characteristics of reserve officers and sergeants, constituting an essential basis of the mobilization reserve of the Armed Forces and other power structures of the state, national security, protection of its national interests.

In General, the improving the system of training officers and sergeants of the reserve in the universities of Kazakhstan on the modern stage of development dictates the need for a system that meets the actual and future mobilization needs of the Armed Forces, taking into account tendencies of development of military science and experience of leading foreign countries.

As a result, the following results are expected:

- expanding opportunities to train specialists in the most popular military specialties;
- providing and maintaining the necessary volumes of the mobilization reserve of officers and non-commissioned officers;

- improving the training of the reserve for additional recruitment of primary positions of officers of the armed forces of the Republic of Kazakhstan for the current shortage; - effective use of the existing potential of military departments, taking into account their regional location, which will solve not only the issues of recruitment in peacetime and wartime, but also the issues of military-Patriotic education and countering the negative impact of information on young people.

\section{CONCLUSION}

The proposed stages of implementation of ways to improve military-Patriotic education of students will allow to fulfill the tasks set by Elbasy to improve the system of military personnel that meet the modern requirements of the Kazakh army in terms of professionalization, since the proposed ways to improve military training in higher education institutions will allow to prepare a highly professional mobilization reserve, partially close the current shortage of officer positions in the armed forces of Kazakhstan, and also to raise the military-Patriotic education of students to a new level, which will undoubtedly have a positive impact on improving the defense capability of the Republic of Kazakhstan.

\section{ACKNOWLEDGEMENT}

The authors are very grateful to the Ministry of education and Science of the Republic of Kazakhstan for providing financial assistance in conducting this research.

\section{REFERENCES}

1. Breunl T. Embedded robotic systems: design and application of mobile robots with embedded control systems. - Moscow: IKI, 2012. $-520 \mathrm{p}$.

2. H. Nyquist. Certain topics in telegraph transmission theory. Trans. AIEE, vol. 47, pp. 617-644, Apr. 1928.

3. Zhantlesov Zh. Kh., Gruzin V. V., Zhantlesov.E. Zh. "Method of object scanning" patent of the Republic of Kazakhstan No. 32026 dated 31.03.2017.

4. Watts, A.C.; Ambrosia, V.G.; Hinkley, E.A. Unmanned aircraft systems in remote sensing and scientific research: Classification and considerations of use. Remote Sens. 2012, 4, 1671-1692.

5. Dalamagkidis, K. "UAV Applications" in Handbook of Unmanned Aerial Vehicles; Springer: Berlin/Heidelberg, Germany, 2015; pp. 2639-2860.

6. Salamí, E.; Barrado, C.; Pastor, E. UAV flight experiments applied to the remote sensing of vegetated areas. Remote Sens. 2014, 6, 11051-11081.

7. Whitehead, K.; Hugenholtz, C.H. Remote sensing of the environment with small unmanned aircraft systems (UASs), part 1: A review of progress and challenges. J. Unmanned Veh. Syst. 2014, 2, 69-85. 
8. Gonzalez, L.F.; Montes, G.A.; Puig, E.; Johnson, S.; Mengersen, K.; Gaston, K.J. Unmanned aerial vehicles (UAVs) and artificial intelligence revolutionizing wildlife monitoring and conservation. Sensors 2016, 16, 97.

9. Achille, C.; Adami, A.; Chiarini, S.; Cremonesi, S.; Fassi, F.; Fregonese, L.; Taffurelli, L. UAV-based photogrammetry and integrated technologies for architectural applications-Methodological strategies for the after-quake survey of vertical structures in Mantua (Italy). Sensors 2015, $15,15520-15539$.

10. Bhardwaj, A.; Sam, L.; Bhardwaj, A.; Martín-Torres, F.J. LiDAR remote sensing of the cryosphere: Present applications and future prospects. Remote Sens. Environ. 2016, 177, 125-143.

11. Royo, P.; Pastor, E.; Barrado, C.; Cuadrado, R.; Barrao, F.; Garcia, A. Hardware Design of a Small UAS Helicopter for Remote Sensing Operations. Drones 2017, 1, 3.

12. Royo, P.; Barrado, C.; Cuadrado, R.; Pastor, E.; Barrao, F.; Garcia, A. Development of a small UAS helicopter for remote sensing operations. In Proceedings of the 2016 IEEE/AIAA 35th Digital Avionics Systems Conference (DASC), Sacramento, CA, USA, 25-29 September 2016; pp. $1-25$.

13. MacFarlane, J.W.; Payton, O.D.; Keatley, A.C.; Scott, G.P.; Pullin, H.; Crane, R.A.; Smilion, M.; Popescu, I.; Curlea, V.; Scott, T.B. Lightweight aerial vehicles for monitoring, assessment and mapping of radiation anomalies. J. Environ. Radioact. 2014, 136, 127-130.

14. Martin, P.G.; Payton, O.D.; Fardoulis, J.S.; Richards, D.A.; Scott, T.B. The use of unmanned aerial systems for the mapping of legacy uranium mines. J. Environ. Radioact. 2015, 143, 135-140.

15. Martin, P.G.; Payton, O.D.; Fardoulis, J.S.; Richards, D.A.; Yamashiki, Y.; Scott, T.B. Low altitude unmanned aerial vehicle for characterising remediation effectiveness following the FDNPP accident. J. Environ. Radioact. 2016, 151, 58-63.

16. Martin, P.G.; Kwong, S.; Smith, N.T.; Yamashiki, Y.; Payton, O.D.; Russell-Pavier, F.S.; Fardoulis, J.S.; Richards, D.A.; Scott, T.B. 3D unmanned aerial vehicle radiation mapping for assessing contaminant distribution and mobility. Int. J. Appl. Earth Obs. Geoinf. 2016, 52, 12-19.

17. Martin, P.G.; Moore, J.; Fardoulis, J.S.; Payton, O.D.; Scott, T.B. Radiological assessment on interest areas on the sellafield nuclear site via unmanned aerial vehicle. Remote Sens. 2016, 8, 913.

18. Aleotti, J.; Micconi, G.; Caselli, S.; Benassi, G.; Zambelli, N.; Calestani, D.; Zanichelli, M.; Bettelli, M.; Zappettini, A. Unmanned aerial vehicle equipped with spectroscopic CdZnTe detector for detection and identification of radiological and nuclear material. In Proceedings of the 2015 IEEE Nuclear Science Symposium and Medical Imaging Conference (NSS/MIC), San Diego, CA, USA, 31 October-7 November 2015; pp. 1-5.

19. Cai, C.; Carter, B.; Srivastava, M.; Tsung, J.; Vahedi-Faridi, J.;Wiley, C. Designing a radiation sensing UAV system. In Proceedings of the 2016 IEEE Systems and
Information Engineering Design Symposium (SIEDS), Charlottesville, VA, USA, 29-29 April 2016; pp. 165-169. 20. Behnke, D.; Rohde, S.;Wietfeld, C. Design and experimental validation of $\mathrm{UAV}$-assisted radiological and nuclear sensing. In Proceedings of the 2016 IEEE Symposium on Technologies for Homeland Security (HST), Waltham, MA, USA, 10-11 May 2016; pp. 1-6.

21. Sydyknazarov, M.-A., Karzhaubay, J., Sydyknazarova, S., Bayurzhan, M. Values of the youth of Kazakhstan. New Educational Review, 2018, 52(2), c. 137-148.

22. Li, B.; Zhu, Y.;Wang, Z.; Li, C.; Peng, Z.R.; Ge, L. Use of multi-rotor unmanned aerial vehicles for radioactive source search. Remote Sens. 2018, 10, 728.

23. Royo, P.; Perez-Batlle, M.; Cuadrado, R.; Pastor, E. Enabling dynamic parametric scans for unmanned aircraft system remote sensing missions. J. Aircr. 2014, 51, 870-882. 24. mRo Pixhawk Flight Controller (Pixhawk 1). Available online:

https://docs.px4.io/en/flight_controller/mro_pixhawk.html (accessed on 10 September 2018).

25. Meier, L.; Tanskanen, P.; Heng, L.; Lee, G.H.; Fraundorfer, F.; Pollefeys, M. PIXHAWK: A Micro Aerial Vehicle Design for Autonomous Flight Using Onboard Computer Vision. Auton. Robots 2012, 33, 21-39. [CrossRef]

26. PX4 Flight Stack. Available online: http://px4.io/ (accessed on 10 September 2018).

27. Ardupilot Flight Stack. Available online: http://ardupilot.org/copter/ (accessed on 10 September 2018). 28. SF11/C (120 m) Lightware Laser Altimeter. Available online: https://lightware.co.za/products/sf11-c-120-m (accessed on 10 September 2018).

29. Mission Planner Overview. Available online: http://ardupilot.org/planner/docs/mission-planner-overview. html (accessed on 10 September 2018).

30. Aubakirova, G., Adilbekov, Z., Narbayev, S. Influence of water mineralization on zooplankton productivity in reservoirs of Akmola region. Periodico Tche Quimica, 2020, 17(34), c. 520-527

31. Raspberrry $\mathrm{Pi} 3$ Model $\mathrm{B}+$. Available online: https://www.raspberrypi.org/products/raspberry-pi-3-modelb - plus/ (accessed on 10 September 2018).

32. RITEC Radiation Micro Spectrometer uSPEC. Available online: http://www.ritec.lv/uspec.html (accessed on 10 September 2018).

33. DJI F550 ARF. Available online: https://www.dji.com/es/flame-wheel-arf (accessed on 11 September 2018).

34. Gilmore, G. Practical Gamma-Ray Spectroscopy; John Wiley \& Sons Ltd.: West Sussex, UK, 2008.

35. International Atomic Energy Agency (IAEA). Safety of Radiation Sources: International Basic Safety Standards, General Safety Requirements, IAEA Safety Standards Series No. GSR Part 3; IAEA Publications: Vienna, Austria, 2014.

36. Aubakirova, G.A., Pishenko, Y.V., Maikanov, B.S. Comprehensive study of the Ashykol and Kumkol lakes of 
Akmola Oblast of the North Kazakhstan. Mediterranean Journal of Social Sciences, 2014, 5(23), c. 2607-2611

37. Aubakirova, G.A., Syzdykov, K.N., Kurzhykayev, Z., Sabdinova, D.K., Akhmedinov, S.N. Quantitative development and distribution of zooplankton in medium lakes of the Kostanay Region (North Kazakhstan Region). International Journal of Environmental and Science Education, 2016, 11(15), c. 8193-8210, ijese. 2016.620

38. Somzhurek, B.Z., Yessengaliyeva, A.M., Medeubayeva, Z.M., Makangali, B.K. Central Asia and regional security. Communist and Post-Communist Studies, 2018, 51(2), c. 161-171.

39. Sempau, J.; Badal, A.; Brualla, L. A PENELOPE-based system for the automated Monte Carlo simulation of clinacs and voxelized geometries-Application to far-from-axis fields. Med. Phys. 2011, 38, 5887-5895.

40. Gasull, M.; Royo, P.; Cuadrado, R. Design a RPAS Software Architecture over DDS. Master's Thesis, Castelldefels School of Telecommunications and Aerospace Engineering, Castelldefels, Spain, 2016.

41. Garro Fernandez, J.M. Drone Configuration for Seaside Rescue Missions. Master's Thesis, Universitat Politècnica de Catalunya, Barcelona, Spain, 2017.

42. Makangali, B., Amirbekova, S., Khamitova, M., Baydarov, E. Religious aspects of the Syrian crisis on social media. Central Asia and the Caucasus, 2020, 21(1), c. 102-111.

43. Macias, M. Study of 4G Propagation Conditions Using Unmanned Aerial Systems. Ph.D. Thesis, Universitat Politècnica de Catalunya, Barcelona, Spain, 2018.

44. Cloud Cap Technology. Piccolo II Product. 2017. Available online: http://www.cloudcaptech.com/products/ detail/piccolo-ii (accessed on 7 July 2017).

45. Makangali, K. Konysbaeva, D.; Zhakupova, G.; Gorbulya, V.; Suyundikova, Zh. Study of sea buckthorn seed powder effect on the production of cooked-smoked meat products from camel meat and beef. Periodico Tche Quimica, 2019, 16: 130-139.

46. Lisitsyn A., Makangali K., Uzakov Y., Taeva A., Konysbaeva D., Gorbulya, V (2018) Study of the National Cooked Smoked Meat Products While Tests with Laboratory Animals at the Pathology Models with the Purpose to Confirm the set of Biocorrective Features. Current Research in Nutrition and Food Science journal 6(2): 536-551.

47. 38. Guava EventBus. Available online: https://github.com/google/guava/wiki/EventBusExplained (accessed on 12 September 2018).

48. 39. Message Queuing Telemetry Transport (MQTT). Available online: http://mqtt.org/ (accessed on 12 September 2018).

49. 40. MAVLink Micro Air Vehicle Communication Protocol. Available online: http://qgroundcontrol.org/ mavlink/start (accessed on 12 September 2018).

50. 41. Hibernate. Available online: http://hibernate.org/ (accessed on 12 September 2018).
51. 42. H2 Database Engine. Available online: http://www.h2database.com/html/main.html (accessed on 12 September 2018).

52. 43. European Accreditation. EA-4/02 M: 2013 Evaluation of the Uncertainty of Measurement in Calibration. 2013. p. 75.

53. Dulambaeva, R., Orazalin, R., Tulembayeva, A., Peruashev, A. Assessing the development effect of governance. Life Science Journal, 2014, 11(SPEC. ISSUE 4), c. $144-152$

54. Tulembayeva, A., Togusov, A., Berdibekov, A., Zhakashev, A. Assessment of the economic potential of the region in the context of national security. Journal of Advanced Research in Dynamical and Control Systems, 2020, 12 (7 Special Issue), c. 1346-1352

55. Alexey Semchenko, Aigul Tulembayeva. Cataloging of supplies for the armed forces as a mechanism for improving their technical support in the interest of increasing the level of military security. Journal of Advanced Research in Dynamical and Control Systems, 2020, 12(7 Special Issue), c. 1353-1367. 


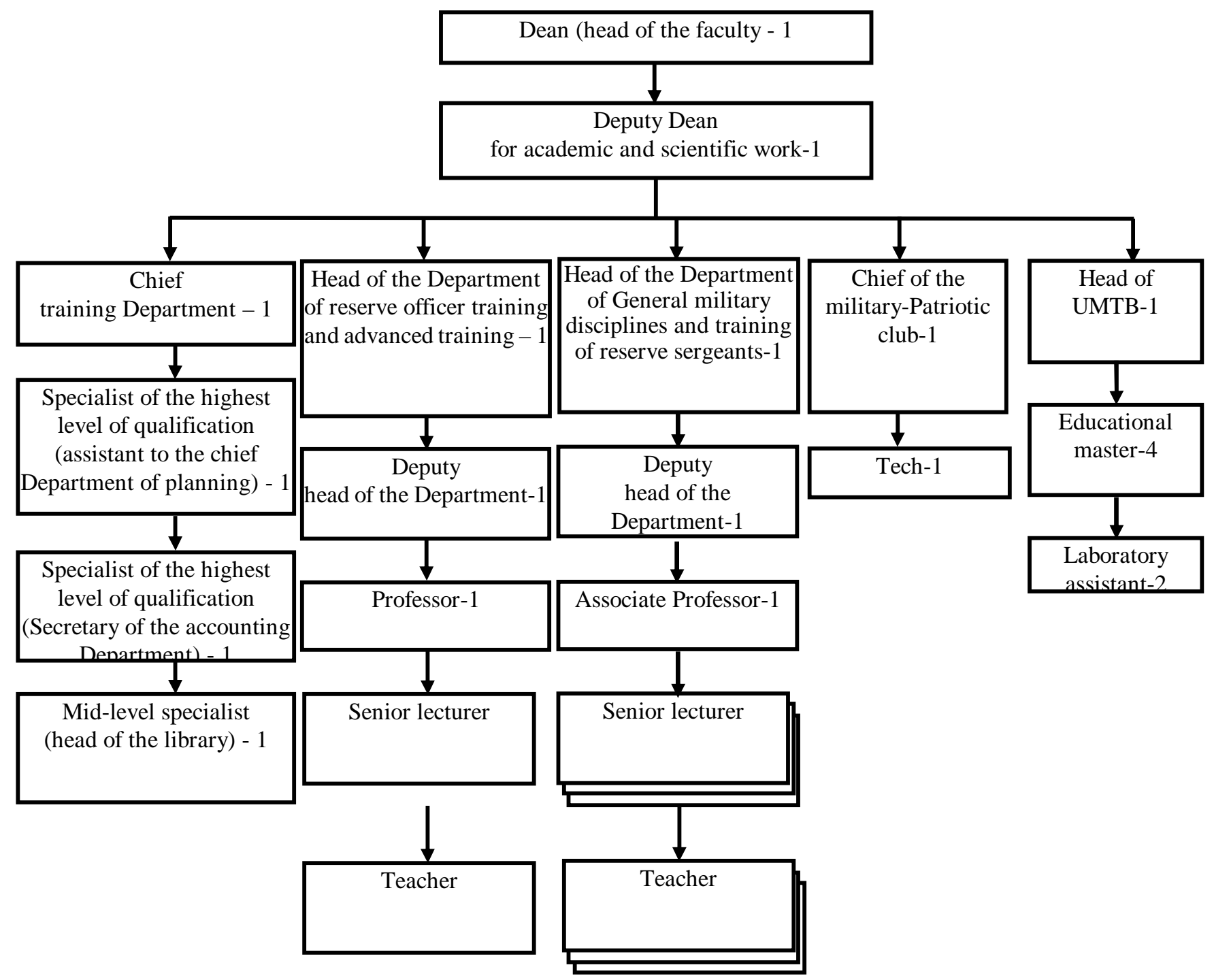

Figure 3: Typical organizational and staff structure faculty of military affairs and patriotic education 